\title{
Leadership of the School Principal in Shaping Early Childhood Characters: A Literature Review
}

\author{
Rama Karo Karo' ${ }^{1}$, Dedy Hermanto Karwan ${ }^{2}$, Riswanti Rini ${ }^{3}$, Sowiyah ${ }^{4}$, Alifa Soraya Nuryadika ${ }^{5}$ \\ ${ }^{1}$ Student of Education Administration, Universitas Lampung, Bandar Lampung, Indonesia \\ ${ }^{2,3,4}$ Lecturer of Education Administration, Universitas Lampung, Bandar Lampung, Indonesia \\ ${ }^{5}$ Student of Education Administration, Universitas Lampung, Bandar Lampung, Indonesia
}

\begin{abstract}
This research to know the leadership of the headmaster in shaping the character of early childhood. The review process begins with a search engine (Google Scholar) to search for articles. The results of the study mostly show that principal leadership is one of the alternative ways to build the character integrated in the school policy, with the inclusion of the character values of environmental concern, religion, autonomy, love of homeland, courtesy and courtesy into learning. To create Indonesia's golden generation all elements of society must contribute to supporting each government program to improve the quality of Indonesian people by improving character education.
\end{abstract}

KEYWORDS: Characters; Education; Leadership; Principal; School

\section{INTRODUCTION}

Printing a superior generation amid global competition can be done by organizing an education that provides opportunities widest to the students to grow and develop according to their potential, talents, interests and ability. This education can be done since early childhood. A researcher on education and globalization Bottery (2006) Reveals that "the ability to learn continuously is a necessity in an environment where human knowledge, imagination, and creativity are key elements of the global economy where education is better when implemented from an early age". Education must deliver children to become citizens of the world but do not be faded from Indonesian human identity. Curriculum 2013 Emphasizes the quality of the learning process, and learning will emphasize student initiatives. The curriculum also emphasizes on ongoing assessment because it is not a cognitive aspect but also continually to the character.

Character education is one of the fundamental efforts of creating a learning situation that meets the needs of student's selfdevelopment in learning interactions designed to form students with character from the environment. As an educational institution, schools play an important role in the formation of student characters. With hope, through character education, will make students as a righteous personage to God Almighty, have a strong faith to give birth of a personal who is virtuous, tolerant of others, have a fighting motivation and able to work hard, accomplished and disciplined, With the character education, students will be well formed so that this nation will have a noble morality. In the formation of quality characters, it is necessary to do construction from an early age. Tilaar renders the term character or in Bahasa Indonesia translated by character is the intrinsic nature of one or a group or nation that is very prominent so that it can be recognized in various situations or is a trade mark of one person. So that the printed generation has intelligence in terms of cognitive, affective and psychomotor. This will strengthen the National foundation towards a better nation (M. Y. Abdullah, Hastuti, \& Karmila, 2015).

In this context, there are two main roles that the school must play, which is educating students with diverse subjects, cognitive skills and knowledge, and educating students in individual and social development. Therefore, the school has a leading role in character education as a social capital of students in their life (Widodo, 2019). If the young generation of this nation is not educated with a noble character this nation will be destroyed, as what Thomas Lickona cited by Agus Wibowo in his book Character Education: Strategy to build a civilizable nation character, which says: A nation is heading for destruction, when the character is thrilled (Simanjuntak, 2019).

The principal is responsible for all school activities and plays an important role in improving the quality of education, the principal's leadership is one of the factors that affect the quality of the school (Setiyati, 2014). The leadership of the headmaster is crucial to the success of the school organization because the leader creates positive change in education by encouraging the existing staff to 


\title{
International Journal of Current Science Research and Review
}

\author{
ISSN: 2581-8341
}

\section{Volume 04 Issue 09 September 2021}

DOI: 10.47191/ijcsrr/V4-i9-09, Impact Factor: 5.825

take the initiative and change to the achievement of effective and efficient school management (Quin, Deris, Bischoff, \& Johnson, 2015), (Aprilana, Kristiawan, \& Hafulyon, 2017). The role of headmaster is very important in the process of learning the education, performance and outcomes of students because the quality of the school leaders is based on students ' academic success; Therefore, schools must invest in training and development of the principal's leadership (Jones et al., 2015). The leadership of the headmaster affects the potential of students in various ways through instrusional and non-instrumentalized tasks, the level and way that the principal's leadership affects student learning outcomes depending on the specific behaviour and features of the school's overall environment, the principal, teacher, student and community context (Urick, 2016).

As a person who has the highest authority and right in the school, in this case there are seven tasks that must be performed by the principal that is: an educator, someone who is a regulator, a person's administration, someone who performs supervision, a person who leads, someone who gives innovation, someone who gives motivation (Murniati, 2018). In short, the headmaster plays a key role in this domain by shaping the school environment, motivating and supporting sustainable learning in school staff (Lijuan, Hallinger, \& Ko, 2016) The proper leadership of the principal in shaping the character of gold generation is crucial. The demographic Bonus must be well-addressed, where the number of productive population is greater than the population of non-productive age. It can be said the leadership role of the principal has a big impact on the formation of golden generation characters. Skill and character development is one of the important efforts in equipping Indonesian youth today preparing for global economic competition (Rina et al., 2018). Based on the above description, researchers feel the need to know more about "how the principal's leadership in shaping Indonesian generation character?"

\section{LITERATURE REVIEW}

\section{Leadership of the School Principal}

The leadership of the headmaster is crucial to the success of the school organization because leaders create positive changes in education by encouraging the existing staff to take the initiative and change (Quin et al., 2015). The potential of students can be influenced by the leadership of the headmaster in various ways through instrusional and non-instrumentalized tasks, the level and way that the principal's leadership affects the student's learning outcomes depending on their particular behaviour and the overall features of the school environment, the principal, teacher, student and community context. (Urick, 2016).

The role of headmaster is very important in the process of learning the education, performance and outcomes of students because the quality of the school leaders is based on students ' academic success; Therefore, schools must invest in training and development of the principal's leadership (Jones et al., 2015) (Tingle, Corrales, \& Peters, 2019). In short, the headmaster plays a key role in this domain by shaping the school environment, motivating and supporting sustainable learning in school staff (Lijuan et al., 2016). Three types of profile principal leaders identified: "Profiles that think people", "Administratife-minded profiles" and "moderatepickling profiles" (Dou, Devos, \& Valcke, 2017).

\section{Character Education}

Character education requires the right method to achieve educational objectives so that teachers should be able to integrate character education into everyday life. In addition, teachers should choose suitable learning methods so that students easily understand the characters they are teaching. In addition to integrated learning, character education can also be integrated through Intracurricular, Kokuricular, and co-curricular activities. Character education can be implemented by programming and school activities (Azhary, Handoyo, \& Khafid, 2018). Character is an integral part that must be built, so that the younger generation as the nation hopes, as the responsible generation decides the future, must have attitudes and intelligence on strong morality and correct in building the nation's efforts. (Maryam, Ummah, Munjin, \& Faris, 2017)

The character education in Indonesia is to develop and to familiarize the moral values and norms of Pancasila in our daily lives to have a peaceful and good life. The purpose of character education is to develop the character of the nation in Indonesia to allow Indonesian people to do the values of Pancasila. The character of educational function as (1) develops the fundamental potential of people in order to be well-hearted, to have good thoughts, and to do good behavior; (2) Strengthening and developing multucultural behavior, and to improve the cultural life of the competitive nation in Indonesia's life relations of the world. (Supriyono, 2016) Character education is not just merely teaching true or false, but more than that it is in addition to this habituation habit of which is good. Learners will then know and understand the values of good or the right things (cognitive), can feel the value and the norm (affective), and capable of doing good behavior (psychomotor). Character education involves moral knowledge, moral feelings, and 


\section{International Journal of Current Science Research and Review}

ISSN: 2581-8341

\section{Volume 04 Issue 09 September 2021}

DOI: 10.47191/ijcsrr/V4-i9-09, Impact Factor: 5.825

moral actions. Thus, the character means the values and norms that correspond to the national values and norms based on the national philosophy of Pancasila. (Supriyono, 2016)

Through the school's characteristic education, this can encourage students to do so has noble character values, such as respect and attention to others, responsibilities, discipline and many more values that need to be implemented. (Murwaningsih, Fadhilah, \& Sholeh, 2020). To be able to implement education in shaping the human character of Indonesia and get maximum results, you must first know the purpose and function of character education. The following functions of character education objectives as stated by the Ministry of Education are: a). Develop the potential participants of the trainees ' heart/conscience/affective as human beings and citizens who have cultural values and national character, b). Develop the habits and attitudes of the students who are praised and in line with the universal values and cultural traditions of the religious nation, c). Instill the spirit of leadership and responsibility of learners as a future generation, d). Developing the ability of learners to become human is independent, creative, knowledgeable, and E). Developing a school environment as a learning environment safe, honest, full of creativity and friendship, as well as with a sense of high nationality and strength. (Jamrah, 2017)

Character education is a teacher's effort to help shape the students ' characters. In addition to the term character, we also know the word adab and morality. Judging from the point of understanding the word character, Adab, morality has no significant difference. These three are defined as actions that occur without thought anymore because they are already embedded in the mind, and in other words, all three can be called by habits (Anggi, 2018).

\section{METHOD}

This library's review focuses on the leadership of the school principal in shaping the students ' characters. Using the search and review methods, the review process starts with a search engine, Google scholar, to search for articles by keyword: "Leadership of the principal and student character". "The search ranged between 2015-2019 and identified in total 150 articles.

The criteria for inclusion in this study are as follows:

a) Quantitative and qualitative results of school principal's leadership in shaping students ' characters.

b) This research was conducted in the world.

c) The study used English.

d) Dissertations and theses excluded.

\section{RESULT AND DISCUSSION}

This literature review focus on the leadership of the headmaster in shaping the character of early childhood.

Table 1. Leadership of the School Principal in Shaping Student Character

\begin{tabular}{|c|c|c|c|c|c|}
\hline $\begin{array}{l}\text { Author } \\
\text { and Year }\end{array}$ & Title & Country & $\begin{array}{l}\text { Method of } \\
\text { Result }\end{array}$ & Sample & Results \\
\hline $\begin{array}{l}\text { Michelle } \\
\text { Jones at al. } \\
(2015)\end{array}$ & $\begin{array}{l}\text { Contemporary } \\
\text { challenges and } \\
\text { changes: principals' } \\
\text { leadershippractices in } \\
\text { Malaysia }\end{array}$ & Malaysia & Quantitative & $\begin{array}{l}7 \quad \text { System } \\
\text { Leadership } \\
\text { Studies }\end{array}$ & $\begin{array}{l}\text { Empirical evidence that emerged about } \\
\text { the leadership practices of the } \\
\text { headmaster and highlighted some of the } \\
\text { challenges associated with the } \\
\text { expectation of new accountability and the } \\
\text { demands given to actors in Malaysia. }\end{array}$ \\
\hline $\begin{array}{l}\text { Lijuan Li, } \\
\text { Philip } \\
\text { Hallinger } \\
\text { and James } \\
\text { Ko (2016) }\end{array}$ & $\begin{array}{l}\text { Principal leadership } \\
\text { and school capacity } \\
\text { effects on teacher } \\
\text { learning in Hong } \\
\text { Kong. }\end{array}$ & Hong Kong & $\begin{array}{l}\text { Cross- } \\
\text { sectional and } \\
\text { quantitative } \\
\text { methods }\end{array}$ & $\begin{array}{l}32 \\
\text { Elementary } \\
\text { School }\end{array}$ & $\begin{array}{l}\text { Various dimensions of principal } \\
\text { leadership contribute significantly to the } \\
\text { school capacity and professional learning } \\
\text { of teachers. The presence of cooperation, } \\
\text { trust, communication, support for } \\
\text { students, and alignments, coherence, and } \\
\text { structuredi Teaching Professional } \\
\text { learning. Research constraints/ } \\
\text { implications }\end{array}$ \\
\hline
\end{tabular}


ISSN: 2581-8341

Volume 04 Issue 09 September 2021

DOI: 10.47191/ijcsrr/V4-i9-09, Impact Factor: 5.825

\begin{tabular}{|c|c|c|c|c|c|}
\hline $\begin{array}{l}\text { Diya Dou, } \\
\text { Geert } \\
\text { Devos and } \\
\text { Martin } \\
\text { Valcke } \\
(2017)\end{array}$ & $\begin{array}{l}\text { The relationships } \\
\text { betweenschool } \\
\text { autonomy gap, } \\
\text { principal leadership, } \\
\text { teachers' } \\
\text { jobsatisfaction and } \\
\text { organizationalcommit } \\
\text { ment }\end{array}$ & China & Quantitative & $\begin{array}{l}528 \text { teacher } \\
\text { and } 59 \text { head } \\
\text { schoolgirl }\end{array}$ & $\begin{array}{l}\text { Significant instructional and } \\
\text { transformational leadership in job } \\
\text { satisfaction teachers and organizational } \\
\text { commitments, mediated by the indirect } \\
\text { impacts of the school climate and self- } \\
\text { efficacy teachers. The school's } \\
\text { Autonomy gap, which is closely related } \\
\text { to the headmaster's leadership, emerged } \\
\text { as an important influence in the pathway } \\
\text { model }\end{array}$ \\
\hline $\begin{array}{l}\text { Shovi } \\
\text { Maryam, } \\
\text { Fathiyatul } \\
\text { Ummah, } \\
\text { Ahmad } \\
\text { Munjin } \\
\text { Nasih } \\
(2017)\end{array}$ & $\begin{array}{l}1 \text { Hour Q-Time as a } \\
\text { Preventive Effort of } \\
\text { Juvenile } \\
\text { Delinquencies to } \\
\text { Prepare the Golden } \\
\text { Generation of } \\
\text { Indonesia } 2045\end{array}$ & Indonesia & Qualitative & - & $\begin{array}{l}\text { Describing the idea of creating new } \\
\text { innovative programs to improve family } \\
\text { harmonization with character education }\end{array}$ \\
\hline $\begin{array}{l}\text { Supriyono } \\
(2016)\end{array}$ & $\begin{array}{l}\text { Develoving } \text { Character } \\
\text { Education With } \\
\text { Reference To Islamic } \\
\text { Perspective: A } \\
\text { Conceptual Review }\end{array}$ & Indonesia & Qualitative & - & $\begin{array}{l}\text { Character education in Indonesia has } \\
\text { already become a priority and its } \\
\text { implications are mandated to be included } \\
\text { in all important subjects through } \\
\text { curricular and extra-curricular activities. } \\
\text { Practical effective implementation } \\
\text { should be taken care of. The development } \\
\text { of suggestive and implementation of } \\
\text { character education includes } \\
\text { strengthening the value of such people in } \\
\text { the Brotherhood, being a good creature of } \\
\text { God as in faith, and capable of doing } \\
\text { good deeds and moral actions in society } \\
\text { as in Islam }\end{array}$ \\
\hline $\begin{array}{l}\text { Tri } \\
\text { Murwanin } \\
\text { gsih, Siti } \\
\text { Sutarmi, } \\
\text { Fadhilah } \\
\text { Abdul } \\
\text { Rozaq } \\
\text { Sholeh } \\
\text { (2020) }\end{array}$ & $\begin{array}{l}\text { The Implementation } \\
\text { of Characters' Values } \\
\text { Through Local } \\
\text { Wisdom of Sadranan } \\
\text { in Elementary } \\
\text { Schools }\end{array}$ & Indonesia & Qualitative & - & $\begin{array}{l}\text { The application of local wisdom can be } \\
\text { achieved by habituation and integrating } \\
\text { the values of local wisdom into class } \\
\text { lessons }\end{array}$ \\
\hline $\begin{array}{l}\text { Alfian } \\
\text { Jamrah } \\
(2017)\end{array}$ & $\begin{array}{lr}\text { Shaping } & \text { Golden } \\
\text { Generation } & \text { Through } \\
\text { Character } & \text { Education } \\
\text { Toward } 100 & \text { Years } \\
\text { Indonesia } & \end{array}$ & Indonesia & Qualitative & - & $\begin{array}{l}\text { The golden generation must be prepared } \\
\text { from now through education. In addition } \\
\text { to building knowledge competencies } \\
\text { (cognitive) and Skills (psychomotor), } \\
\text { balance is also very important with } \\
\text { character building (affective). }\end{array}$ \\
\hline
\end{tabular}




\section{International Journal of Current Science Research and Review}

ISSN: 2581-8341

Volume 04 Issue 09 September 2021

DOI: 10.47191/ijesrr/V4-i9-09, Impact Factor: 5.825

\begin{tabular}{|c|c|c|c|c|c|}
\hline $\begin{array}{l}\text { Lijuan Li, } \\
\text { Philip } \\
\text { Hallinger } \\
\text { and James } \\
\text { Ko (2016) }\end{array}$ & $\begin{array}{l}\text { Principal leadership } \\
\text { and school capacity } \\
\text { effects on teacher } \\
\text { learning in Hong } \\
\text { Kong. }\end{array}$ & Hong Kong. & $\begin{array}{l}\text { Cross- } \\
\text { sectional and } \\
\text { quantitative } \\
\text { methods }\end{array}$ & $\begin{array}{l}32 \\
\text { Elementary } \\
\text { School }\end{array}$ & $\begin{array}{l}\text { Various dimensions of principal } \\
\text { leadership contribute significantly to the } \\
\text { school capacity and professional learning } \\
\text { of teachers. The presence of cooperation, } \\
\text { trust, communication, support for } \\
\text { students, and alignments, coherence, and } \\
\text { structure in school also affect teacher } \\
\text { professional learning. } \\
\text { Batasan / implikasi penelitian }\end{array}$ \\
\hline $\begin{array}{l}\text { Anggi Fitri } \\
(2018)\end{array}$ & $\begin{array}{l}\text { Character education } \\
\text { of Al-Quran Hadith }\end{array}$ & Indonesia & Qualitative & - & $\begin{array}{l}\text { The hadith raised in this study contains } \\
\text { human character or behavior towards } \\
\text { God, oneself, fellow human beings, and } \\
\text { the environment. Some concepts of } \\
\text { educational character that can be } \\
\text { expressed from the Quran and Hadith is } \\
\text { the first, basic character education, } \\
\text { second. Concept of character education } \\
\text { in Islam. Third, the stage of character } \\
\text { education formation. Fourth, the } \\
\text { internalization character education } \\
\text { method. Fifth, the role of teachers and } \\
\text { parents in character education. }\end{array}$ \\
\hline
\end{tabular}

Result and discussion should be This section reports the main findings of the article being reviewed. The analysis shows that most articles focus on the principal leadership, students ' characters. Articles that have been reviewed are research conducted in several countries.

Based on the articles reviewed, there are various ways of collecting data related to the leadership of the headmaster and the establishment of a student character. The research methods are used from articles to articles. The most commonly used method is to use interviews and observations used by (Azhary, L., Handoyo, E., \& Khafid, M. 2018), (Dekawati, 2020), (Jamrah, 2017), (Maryam et al., 2017), (R. Simanjuntak, 2019), and (Wardoyo, S. M. 2015).

Research on the leadership of the school principal in shaping students ' characters has been conducted in Indonesia in various organizations and in various countries. Table 1 shows that research has been conducted in schools, universities, and schools. The results of most research show that the principal's leadership is one alternative way to build a character that is integrated in the school's policies, with the inclusion of character values of environmental concern, religion, autonomy, love of homeland, courtesy and courtesy to the vision, Mission and school program. To create a student character all elements of society must play a role in supporting each government program to improve the quality of Indonesian people by improving character education, so that it becomes a whole curriculum to create a strong student character and based on the religious Pancasila.

\section{CONCLUSION}

Its broad conclusion is that when the author considers all the review studies on the leadership of the school principal in the establishment of student characters, it shows that the headmaster's leadership is very important for the establishment of student characters in preparing student's characters.

\section{REFERENCES}

1. Anggi, F. (2018). Pendidikan Karakter Prespektif Al-Quran Hadits. TA'LIM: Jurnal Studi Pendidikan Islam, 1(2). doi:10.29062/ta'lim.v1i2.952 


\section{International Journal of Current Science Research and Review}

ISSN: 2581-8341

Volume 04 Issue 09 September 2021

DOI: 10.47191/ijesrr/V4-i9-09, Impact Factor: 5.825

IJCSRR@ 2021

www.ijcsrr.org

2. Dou, D., Devos, G., \& Valcke, M. (2017). The relationships between school autonomy gap, principal leadership, teachers' job satisfaction and organizational commitment. Educational Management Administration \& Leadership, 45(6), 959-977. doi:10.1177/1741143216653975

3. Jamrah, A. (2017). Shaping Golden Generation through Character Education toward 100 Years Indonesia. Proceeding IAIN Batusangkar, 1(2).

4. Jones, M., Adams, D., Hwee Joo, M. T., Muniandy, V., Perera, C. J., \& Harris, A. (2015). Contemporary challenges and changes: principals' leadership practices in Malaysia. Asia Pacific Journal of Education, 35(3). doi:10.1080/02188791.2015.1056591

5. Lijuan, L., Hallinger, P., \& Ko, J. (2016). Principal leadership and school capacity effects on teacher learning in Hong Kong. International Journal of Educational Management, 30(1). doi:10.1108/IJEM-03-2014-0035

6. Maryam, S., Ummah, F., Munjin, A., \& Faris, A. (2017). 1 Hour Q-Time as a Preventive Effort of Juvenile Delinquencies to Prepare the Golden Generation of Indonesia 2045. Paper presented at the International Conference on Learning Innovation (ICLI 2017).

7. Murwaningsih, T., Fadhilah, S. S., \& Sholeh, A. R. (2020). The Implementation of Characters' Values Through Local Wisdom of Sadranan in Elementary Schools. International Journal of Multicultural and Multireligious Understanding, $7(1)$.

8. Quin, J., Deris, A., Bischoff, G., \& Johnson, J. T. (2015). Comparison of Transformational Leadership Practices: Implications for School Districts and Principal Preparation Programs. Journal of Leadership Education, 14(3). doi:1012806/V14/I3/R5

9. Rina, L., Murtini, W., \& Indriayu, M. (2018). Establishment of entrepreneurial character in the foundation based school system through project based learning. International Journal of Educational Research Review, 3(4). doi:10.24331/ijere.455049

10. Supriyono, S. (2016). Develoving Character Education With Reference To Islamic Perspective: A Conceptual Review. JARES (Journal of Academic Research and Sciences), 1(1).

Cite this Article: Rama Karo Karo, Dedy Hermanto Karwan, Riswanti Rini, Sowiyah, Alifa Soraya Nuryadika(2021). Leadership of the School Principal in Shaping Early Childhood Characters: A Literature Review. International Journal of Current Science Research and Review, 4(9), 1140-1145 